\begin{tabular}{|ll|}
\hline Received & $:$ 30 September 2019 \\
Revised & $: 1$ Oktober 2019 \\
Accepted & $: 22$ Oktober 2019 \\
Online & $: 25$ Oktober 2019 \\
Published & $: 29$ Oktober 2019 \\
\hline
\end{tabular}

\title{
KARAKTERISASI BIOPLASTIK DARI RUMPUT LAUT (EUCHEUMA COTTONII) DAN PATI SINGKONG DENGAN PENAMBAHAN PATI DARI LIMBAH BIJI DURIAN
}

\author{
Amelia Sabella \\ Fakultas Matematika dan Ilmu Pengetahuan Alam, Universitas Negeri Jakarta \\ email: ameliasabella18@gmail.com
}

\begin{abstract}
Plastic waste from petroleum raw materials is difficult to decompose by microbes in the soil. In Indonesia, according to Indonesian domestic waste statistics, the type of plastic waste is ranked second at 5.4 million tons per year or 14\% of total waste production and this number is expected to increase. Anticipating global trends in the use of plastics and their applications in the packaging industry, this research was conducted to synthesize biodegradable seaweed-based plastic (Eucheuma cottonii) mixed with cassava starch and polysaccharides derived from tropical fruit seeds that are widely available in Indonesia, namely durian with a composition composition of 3: 8: 1. Characterization carried out included functional group analysis with FTIR, mechanical properties (tensile strength) and biodegradability. The results showed that durian seed waste has the potential to be used as bioplastics because it has the ability of $87.43 \%$ to be degraded in the soil for 14 days, tensile strength of $4.69 \mathrm{mPA}$ and the result of an extension of $1.92 \%$ and a breakout extension of $2.02 \%$, this is influenced by the composition starch contained in durian seeds is $46.2 \%$ in durian seeds.
\end{abstract}

Keywords: Biodegradable, Bioplastic, Ft-Ir, Starch, Seaweed, Tensile Strength

\begin{abstract}
Abstrak
Limbah plastik dari bahan baku minyak bumi sulit terurai oleh mikroba di tanah. Di Indonesia, menurut statistik limbah domestik Indonesia, jenis sampah plastik berada di peringkat kedua pada 5,4 juta ton per tahun atau $14 \%$ dari total produksi limbah dan jumlah ini diperkirakan akan meningkat. Mengantisipasi tren global dalam penggunaan plastik dan aplikasinya dalam industri pengemasan, penelitian ini dilakukan untuk mensintesis plastik berbasis rumput laut (Eucheuma cottonii) biodegradable dicampur dengan pati singkong dan polisakarida yang berasal dari biji buah tropis yang banyak tersedia di Indonesia, yaitu durian dengan komposisi komposisi 3: 8: 1. Karakterisasi yang dilakukan meliputi analisis gugus fungsi dengan FTIR, sifat mekanik (kekuatan tarik) dan biodegradabilitas. Hasil penelitian menunjukkan bahwa limbah biji durian berpotensi untuk digunakan sebagai bioplastik karena memiliki kemampuan $87,43 \%$ terdegradasi di tanah selama 14 hari, kekuatan tarik 4,69 mPA dan hasil perpanjangan 1,92\% dan breakout. ekstensi 2,02\%, ini dipengaruhi oleh komposisi pati yang terkandung dalam biji durian adalah $46,2 \%$ pada biji durian.
\end{abstract}

Kata kunci: Biodegradable, Bioplastik, Ft-Ir, Pati, Rumput Laut, Kekuatan Tarik 


\section{PENDAHULUAN}

Biji plastik merupakan senyawa polimer organik yang berasal dari minyak bumi yang sudah mengalami proses polimerisasi, polikondensasi, dan poliadisi dari monomermonomernya, sehingga dapat dibentuk sesuai dengan bentuk yang diinginkan (Coles et al. 2003).

Plastik dipilih sebagai bahan baku kantong belanja karena plastik memiliki banyak kelebihan, diantaranya ringan, relatif murah, fleksibel, tahan terhadap air, dan praktis (Gunawan et al. 2007). Kebutuhan akan plastik sangat besar sehingga memicu permasalahan lingkungan di dunia terutama di Indonesia berupa sampah plastik.

Sampah plastik yang berasal dari bahan baku minyak bumi merupakan sampah yang sulit terurai oleh mikroba di dalam tanah. Data yang dikeluarkan oleh Kementerian Lingkungan Hidup dan Kehutanan tahun 2015 menyebutkan jumlah timbunan sampah di Indonesia telah mencapai 175.000 ton/hari atau setara 64 juta ton/tahun (Fahmi, 2018).

Berdasarkan hasil studi yang dilakukan di beberapa kota tahun 2012, pola pengelolaan sampah di Indonesia sebagai berikut: diangkut dan ditimbun di TPA (69\%), dikubur (10\%), dikompos dan didaur ulang (7\%), dibakar (5\%), dan sisanya tidak terkelola (7\%) (Kementrian lingkungan hidup, 2015).

Di samping itu bahan plastik yang berasal dari poliolefin tidak dapat terdegradasi oleh tanah dan jika dibakar akan meleleh dan memadat kembali serta memiliki sifat perintang yang tinggi terhadap permeabilitas $\mathrm{O}_{2}$ dan $\mathrm{CO}_{2}$. (Darni et al., 2008). Dengan adanya sifat perintang tersebut, plastik tidak mudah dilewati oleh $\mathrm{O}_{2}$ dan $\mathrm{CO}_{2}$.

Berdasarkan hal tersebut, salah satu solusi terbaik untuk mengatasi pencemaran lingkungan akibat sampah plastik adalah dengan membuat plastik biodegradable (bioplastik). Bioplastik mempunyai sifat ramah lingkungan karena sifatnya yang dapat kembali ke alam. Bioplastik dirancang untuk memudahkan proses degradasi terhadap reaksi enzimatis mikroorganisme seperti bakteri dan jamur (Avella, 2009).

Salah satu bahan yang dapat digunakan dalam pembuatan bioplastik adalah pati. Pati dapat diubah menggunakan teknologi yang ada, jumlahnya melimpah dan murah (Ali et al., 2008). Selain itu pati digunakan karena merupakan bahan yang mudah didegradasi oleh alam menjadi senyawa-senyawa yang ramah lingkungan (Darni \& Herti, 2010).

Sementara itu, penggunaan plastik biodegradable di Indonesia masih sedikit jumlahnya (Anas et $a l$, 2012). Pati yang digunakan pada umumnya berasal dari bahan makanan pokok atau pengganti makanan pokok. Oleh karena itu, diperlukan pengembangan ke arah bahan yang tidak digunakan sebagai makanan pokok atau pengganti makanan pokok agar tidak mengancam ketersediaan pangan di masa yang akan datang.

Penggunaan plastik yang cukup tinggi berdampak negatif terhadap kelestarian lingkungan (Tokiwa et al. 2009), karena sulit terdegradasi sehingga terjadi penumpukan sampah plastik yang mencemari lingkungan.

Para peneliti dan ilmuwan terus berupaya menghasilkan bahan kemasan plastik yang ramah lingkungan. Beberapa penelitian telah menghasilkan teknologi pembuatan plastik dari bahan alami yang dapat terdegradasi dalam waktu singkat yang disebut sebagai plastik biodegradable atau bioplastik. Plastik biodegradable adalah polimer plastik yang tersusun atas monomer organik yang terdapat pada pati, selulosa, protein dan mikroorganisme. Plastik biodegradable dapat digunakan layaknya plastik konvensional biasa namun akan hancur oleh aktivitas mikroorganisme dan menghasilkan air dan senyawa yang tidak berbahaya bagi lingkungan dan kesehatan ketika dibuang ke lingkungan (Martina, 2016).

Plastik biodegradable adalah suatu bahan dalam kondisi tertentu, waktu tertentu mengalami perubahan dalam struktur kimianya, yang mempengaruhi sifat-sifat dimilikinya karena pengaruh mikroorganisme (bakteri, jamur, alga) (Said, 2018).

Pati merupakan senyawa polisakarida yang terdiri dari monosakarida yang berikatan melalui ikatan oksigen. Monomer dari pati adalah glukosa yang berikatan dengan ikatan $\alpha(1,4)$ - glikosidik, yaitu ikatan kimia yang menggabungkan 2 molekul monosakarida yang berikatan kovalen terhadap sesamanya. 
Pati merupakan zat tepung dari karbohidrat dengan suatu polimer senyawa glukosa yang terdiri dari dua komponen utama, yaitu amilosa dan amilopektin. Polimer linier dari D - glukosa (Martina, 2016).

Pati adalah bahan baku yang paling menarik untuk pengembangan dan produksi bioplastik. Pati tersimpan dalam berbagai tanaman dalam bentuk butiran mikroskopis. Pati dapat dihidrolisis menjadi glukosa oleh mikroorganisme atau enzim, dan kemudian dimetabolisme menjadi karbon dioksida dan air (Dyah, 2000).

Pati dalam pencampuran dengan polimer sintesis dapat meningkatkan kemampuan biodegradasi dikarenakan terjadi peningkatan luasan permukaan polimer sebagai akibat hidrolisis pati oleh mikroorganisme. Mikroorganisme yang mengkonsumsi pati akan membentuk pori-pori dalam matrik polimer dan memberikan gugus-gugus yang rentan untuk terdegradasi (Park Macromolecular Materials and Engineering).

Buah dengan julukan The King of fruits ini termasuk dalam family Bombacaceae dan banyak ditemukan di daerah tropis. Di Indonesia, tanaman durian terdapat di seluruh pelosok Jawa dan Sumatera. Sedangkan di Kalimantan dan Irian Jaya umumnya hanya terdapat di hutan. (Djaeni, 2010).

Menurut Badan Pusat Statistik Republik Indonesia (2011) menyatakan bahwa produksi durian rata-rata terjadi peningkatan dari 17.405 ton pada tahun 1999 menjadi 741.831 ton pada tahun 2003 dan pada akhir tahun 2011 menjadi 883.969 ton. Pemanfaatan biji durian masih terbatas, karena hanya sepertiga dari buah durian yang bisa dimakan, sedangkan biji (20\% sampai $25 \%$ ) dan kulit biasanya dibuang.

Limbah biji durian yang ketersediaannya melimpah dan belum dimanfaatkan secara optimal memiliki kandungan karbohidrat terutama patinya yang cukup tinggi sekitar 43,6\% dibanding dengan ubi jalar 27,9\% atau singkong 34,7\% (Sitomurang, 2009).

Menurut (Afif, 2003), komposisi kimia biji durian hampir sama dengan biji-biji yang termasuk famili Bombacaceae yang lain, komposisi kandungan yang terdapat pada biji durian yang dimasak kadar airnya 51,1 gram, kadar lemak 0,2 gram, kadar protein 1,5 gram, dan kadar karbohidrat 46,2 gram.

Biji dari tanaman yang famili Bombacaceae kaya akan karbohidrat terutama patinya yang cukup tinggi sekitar $42,1 \%$ dibanding dengan ubi jalar 27,9\% atau singkong $34,7 \%$.

Singkong merupakan tanaman dikotil berumah satu yang ditanam untuk diambil patinya yang sangat layak cerna. Pohon singkong dapat tumbuh hingga 1-4 meter dengan daun besar yang menjari dengan 5 hingga 9 belahan lembar daun. Batangnya memiliki pola percabangan yang khas, yang keragamannya tergantung pada kultivar (Rubatzky dan Yamaguchi, 1995).

Pati singkong sering digunakan sebagai bahan tambahan dalam industri makanan dan industri yang berbasis pati karena kandungan patinya yang cukup tinggi. Berikut data kalori dan komposisi zat gizi dalam $100 \mathrm{~g}$ singkong.

Tabel 1. Data Kalori Singkong

\begin{tabular}{ll}
\hline Komposisi Kimia & Jumlah \\
\hline Air $(\mathrm{g})$ & 62.5 \\
Karbohidrat $(\mathrm{g})$ & 34.7 \\
Protein $(\mathrm{g})$ & 1.2 \\
Lemak $(\mathrm{g})$ & 0.3 \\
a (mg0 & 33.0 \\
Fe (mg) & 0.7 \\
Thiamin B1 (mg) & 0.06 \\
Riboflavin B2 (mg) & 0.03 \\
Niacin (mg) & 0.6 \\
Vitamin C (mg) & 36 \\
Energi (kal) & 146.0 \\
\hline
\end{tabular}

e-Journal : http://ejurnal.kpmunj.org 
Salah satu sumber daya alam hayati laut Indonesia yang sangat berpotensi guna memenuhi kebutuhan di dalam negeri maupun ekspor adalah rumput laut. Namun, rumput laut dari Indonesia masih berupa bahan mentah yaitu rumput laut kering.

Rumput laut akan bernilai ekonomis lebih tinggi jika diolah menjadi produk antara berupa agaragar, karaginan, dan alginat serta produk pangan siap konsumsi (Y. 2010)

Ampas rumput laut dapat digunakan sebagai bahan baku biodegradable film. Pada industri rumput laut bagian yang digunakan hanya sekitar $30-35 \%$, sedangkan $65-70 \%$ menjadi limbah yang belum banyak dimanfaatkan (Wekridhany, 2012).

Hasil penelitian yang dilakukan oleh (Melanie, 2013) yang berjudul "Pemanfaatan Pati Biji Durian (Durio zibethinus Murr.) Dan Pati Sagu (Metroxylon sp.) Dalam Pembuatan Bioplastik " pembuatan plastik biodegradable dari pati yang berasal dari biji durian dengan pati dari empulur sagu sebagai pembanding dipakai karakteristik mekanik bioplastik yang dihasilkannya hampir sama dengan bioplastik dari pati sagu dan pati singkong. Penampakan fisik bioplastik yang terbuat dari pati biji durian terlihat lebih gelap daripada bioplastik yang terbuat dari pati sagu karena adanya protein dalam pati biji durian cukup tinggi yang dapat menginduksi terjadinya reaksi pencoklatan.

Hasil penelitian dari (Suryanto, 2016) yang berjudul "Struktur dan Kekerasan Bioplastik dari Pati Singkong" menunjukkan bahwa kekerasan dari bioplastik sangat dipengaruhi oleh jumlah matrik dan jumlah plasticizer yang digunakan. Semakin banyak kandungan tepung tapioka maka semakin kekerasan bioplastik semakin meningkat sedangkan penambahan plasticizer gliserol akan menurunkan kekerasan bioplastik.

Hasil penelitian dari (Verraprinita, 2017) yang berjudul "Aplikasi Rumput Laut Eucheuma cottoni Pada Sintesis Bioplastik Berbasis Sorgum Dengan Plasticizer Gliserol" menunjukkan bahwa formulasi penambahan selulosa Eucheuma cottonii dan konsentrasi plasticizer gliserol pada pembuatan bioplastik berbasis sorgum ini sudah memenuhi standar plastik HDPE pada sifat mekanik, namun belum memenuhi standar pada sifat fisiknya terutama berdasarkan penyerapan air-nya.

Pada penelitian ini menggunakan beberapa sumber pati yang berasal dari biji durian dan pati singkong sebagai bahan dasar bioplastik. Oleh karena kandungan patinya yang cukup tinggi, limbah biji durian dan singkong berpotensi untuk dijadikan bahan baku pembuatan bioplastik, sebagai upaya pengoptimalan pemanfaatan limbah biji durian agar bernilai ekonomis.

Adapun hal tidak dapat dipungkiri bahwa plastik berbahan pati bersifat hidrofilik. Karakteristik bioplastik berbahan dasar rumput laut memiliki sifat mekanik yang lebih baik dibanding bioplastik berbahan dasar pati singkong/jagung karena memiliki kandungan selulosa yang tinggi yang berfungsi sebagai penguat. Selulosa merupakan salah satu polimer alami yang banyak digunakan untuk memperbaiki sifat mekanik bioplastik berbahan dasar pati murni.

Selain itu, rumput laut merupakan bahan yang memiliki potensi besar untuk dikembangkan sebagai bahan baku pembuat bioplastik karena ketersediaannya yang melimpah di Indonesia. Saat ini produksi rumput laut di Indonesia pada tahun 2015 mencapai 1.033.500 ton kering sementara serapan pasar dalam negeri hanya 87.429 ton kering (Zatnika dan Istini, 2007).

Berdasarkan uraian di atas, maka penelitian ini menggunakan pati yang berasal dari limbah biji durian dan pati singkong serta rumput laut dalam sintesa bioplastik yang akan dikarakterisasi dengan beberapa pengujian yaitu uji FTIR untuk mengonfirmasi gugus fungsional dalam film bioplastik, uji tensile strength untuk mengetahui kekuatan pemanjangan (uji tarik) film bioplastik, dan uji biodegradasi untuk mengetahui kemampuan film bioplastik terdegradasi dalam tanah selama 14 hari. 


\section{METODE PENELITIAN}

Tujuan operasional penelitian ini adalah untuk menganalisis hasil karakterisasi bioplastik dari rumput laut (Eucheuma cottonii) dan pati singkong dengan memanfaatkan limbah biji durian.

Metode penelitian ini adalah penelitian eksperimen (true experiment), diartikan sebagai metode yang digunakan untuk mencari pengaruh perlakuan tertentu terhadap yang lain dalam kondisi yang terkendalikan. Metode ini digunakan atas dasar pertimbangan bahwa sifat penelitian eksperimental yaitu mencoba sesuatu untuk mengetahui atau akibat dari suatu perlakuan. Disamping itu peneliti ingin mengetahui pengaruh variabel bebas terhadap variabel terikat yang diselidiki atau diamati.

Pada penelitian ini banyaknya konsentrasi pati biji durian berperan sebagai variabel bebas, sedangkan rumput laut dan pati singkong berperan sebagai variabel terikat. Sampel pada penelitian ini adalah rumput laut yang dihaluskan dengan air, pati hasil ekstraksi biji durian serta pati singkong dengan perbandingan 3:1:8.

Adapun alat dan bahan yang digunakan dalam penelitian ini adalah timbangan analitik, gelas kimia $100 \mathrm{ml}$, gelas ukur $25 \mathrm{ml}$, spatula, batang pengaduk, botol semprot, pipet tetes, spirtus, serta rumput laut, biji durian, dan singkong sebagai bahan utama.

Selanjutnya, desain penelitian dari penelitian ini adalah komposisi bioplastik dengan perbandingan $3: 8: 1$ yang mana terdiri atas pati biji durian + rumput laut + pati singkong lalu dilakukan tiga macam uji karakterisasi yang terdiri atas uji FTIR, uji tensile strength, uji biodegradable.

\section{HASIL DAN PEMBAHASAN}

Hasil sintesis bioplastik yang telah dilakukan dari rumput laut dan pati singkong dengan penambahan pati limbah biji durian pada perbandingan komposisi masing-masing adalah 3:8:1 diperoleh hasil sebagai berikut.

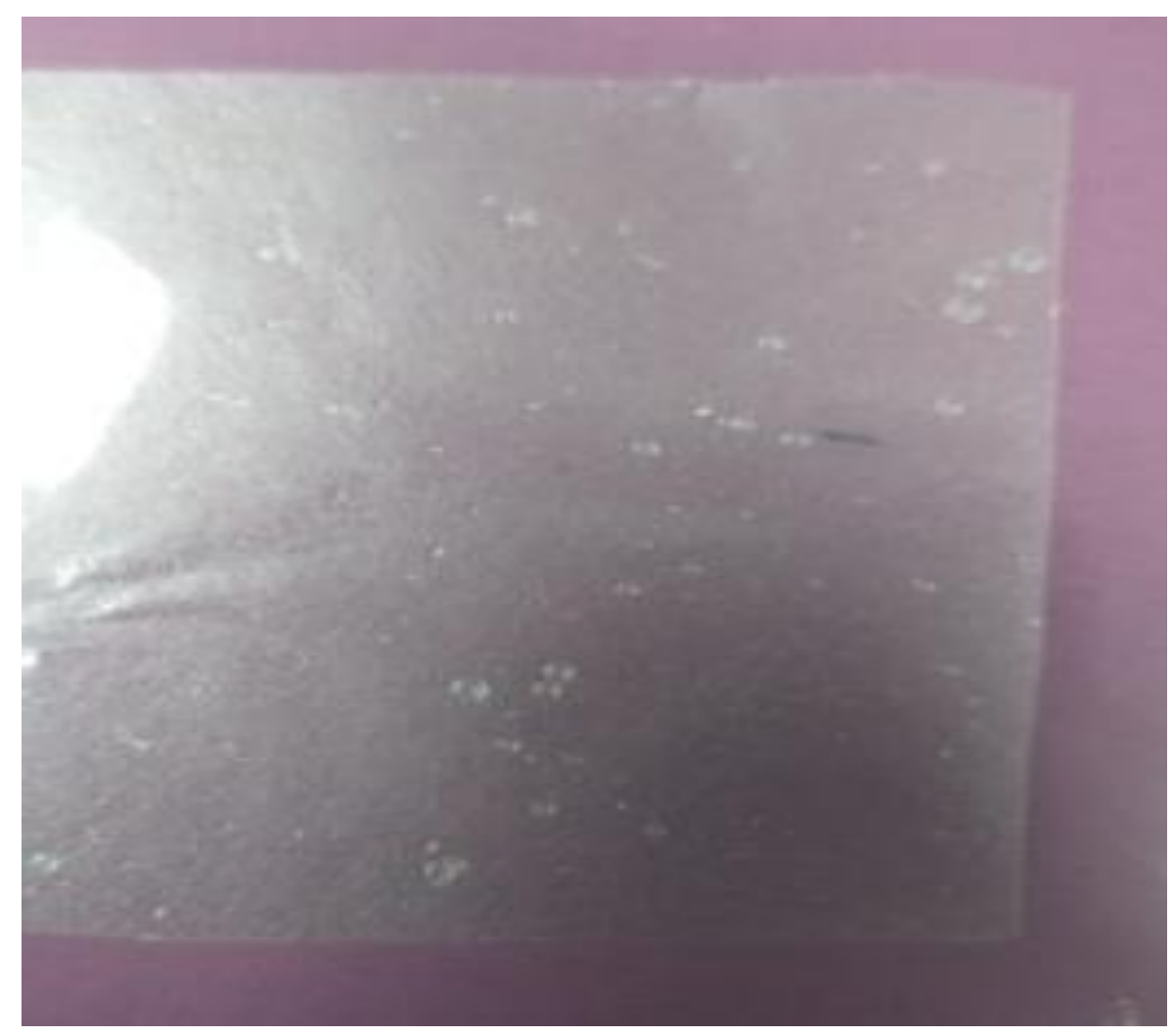

Gambar 1. Hasil Sintesis Bioplastik 
Pembuatan plastik biodegradable berbasis tepung biji durian pada penelitian ini telah dilakukan dan diperoleh plastik biodegradable berupa lembaran plastik yang memiliki warna putih bening.

Setelah berhasil mensintesis bioplastik dari rumput laut dan pati singkong dengan penambahan pati limbah biji durian, karakterisasi dilanjutkan dengan uji FTIR untuk mengetahui gugus-gugus fungsi dari bioplastik durian seperti Gambar 2 (Di halaman berikutnya).

Analisis pada bioplastik dari biji durian terdapat bilangan gelombang $3251 \mathrm{~cm}^{-1}$ yang menunjukkan adanya gugus $\mathrm{O}-\mathrm{H}$ alkohol. Bilangan gelombang $2924 \mathrm{~cm}^{-1}$ menunjukkan ikatan $\mathrm{C}-\mathrm{H}$ alkana. Kemudian bilangan gelombang $1638 \mathrm{~cm}^{-1}$ menunjukkan adanya gugus khas pati yaitu ikatan C-C. Selain itu pada rentang frekuensi 900-1250 cm-1 yaitu 930, 993, 1079 dan $1149 \mathrm{~cm}^{-1}$ menunjukkan adanya gugus $\mathrm{C}-\mathrm{O}$ pada pati (Chandra, 2013). Munculnya bilangan gelombang tersebut pada bioplastik mengindikasi telah terjadi interaksi berupa ikatan hidrogen amilum-amilopektin.

Sedangkan pada bilangan gelombang $600-900 \mathrm{~cm}^{-1}$ adalah daerah fringerprint untuk gugus-gugus yang khas pada biji durian. Analisis gugus fungsi dengan FTIR bertujuan untuk mengetahui proses yang terjadi pada pencampuran apakah secara fisik atau kimia (Satriawan, 2017).

Hasil FT-IR pada bioplastik durian ini menunjukkan tidak adanya kemunculan gugus fungsi yang baru, dengan kata lain secara kimia tidak terjadi perubahan, sehingga proses pembuatan bioplastik merupakan pencampuran secara fisik (A. Sofia, 2017). Untuk mengetahui hasil dari bilangan gelombang gugus fungsional bioplastik pati biji durian dapat dilihat pada Tabel 1.

Tabel 1. Hasil dari bilangan gelombang gugus fungsional bioplastik pati biji durian

\begin{tabular}{ll}
\hline Bilangan Gelombang & Gugus Fungsi \\
\hline $3261 \mathrm{~cm}^{-1}$ & gugus O-H alcohol \\
$2924 \mathrm{~cm}^{-1}$ & ikatan C-H alkane \\
$1638 \mathrm{~cm}^{-1}$ & ikatan C-C \\
$900-1250 \mathrm{~cm}^{-1}$ & gugus C-O pada pati \\
\hline
\end{tabular}

Langkah selanjutnya adalah dengan melakukan uji biodegradasi. Biodegradasi adalah penyederhanaan sebagian atau penghancuran seluruh bagian struktur molekul senyawa oleh reaksireaksi fisiologis yang dikatalisis oleh mikroorganisme (Madsen, 1997 dalam (Ummah 2012)).

Metode yang digunakan adalah metode soil burial test (Subowo dan Pujiastuti, 2003 dalam (Ummah 2012)) yaitu dengan metode penanaman sampel dalam tanah. Sampel berupa film bioplastik ditanamkan pada tanah yang ditempatkan dalam pot dan diamati per-hari terdegradasi secara sempurna. Analisis biodegradasi film plastik dilakukan dengan pengamatan film secara visual melalui penguburan plastik dalam tanah selama 14 hari yang bertujuan untuk dapat melihat dan mengamati besarnya nilai persen kemampuan bioplastik yang terdegradasi dalam tanah. Percobaan laju biodegradasi penguburan dalam tanah ini diamati selama 14 hari dengan hasil presentase karakteristik sintesis bioplastik yang disajikan pada Tabel 2 berikut.

Tabel 2. Hasil Percobaan laju biodegradasi

Film Komposit Biodegradibilitas dalam 14 hari (\%)

KSD $\quad 87.43$

Dalam tabel menunjukan bahwa bioplastik mudah terdegradasi dengan perbandingan komposisi rumput laut : pati singkong : biji durian yaitu 3:8:1 yang dibuktikan dengan hasil persen degradasi sebesar $87,43 \%$. 


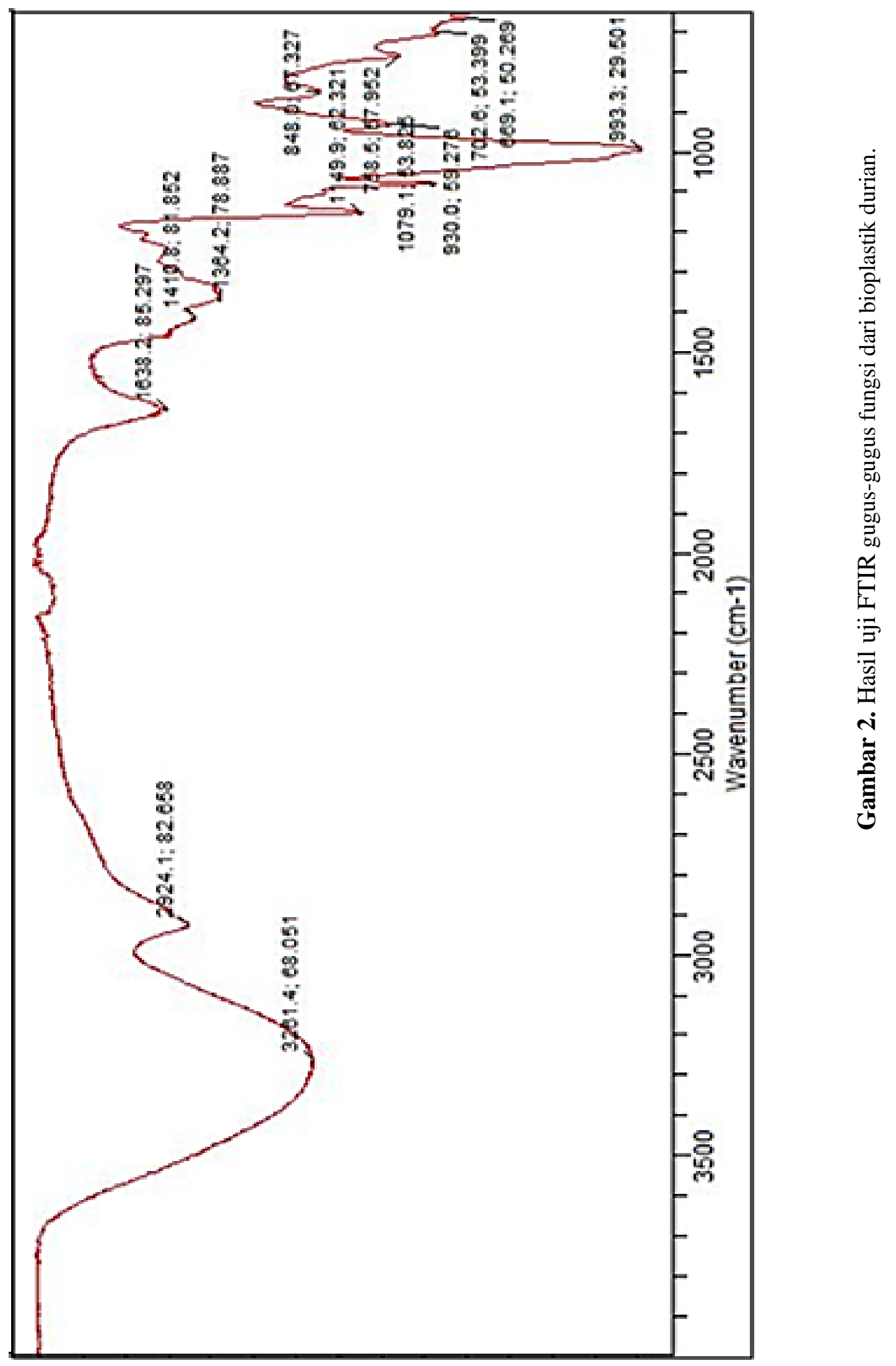


Hal ini terjadi berkaitan dengan hidrolisis pati oleh mikroorganisme, dimana pati dapat dihidrolisis menjadi glukosa oleh mikroorganisme atau enzim, dan kemudian dimetabolisme menjadi karbon dioksida dan air (Dyah, 2000).

Selanjutnya, mikroorganisme akan menguraikan polimer-polimer dengan mengkatalisis hidrolisis dan oksidasi molekul karbohidrat yang dimiliki dalam biji dengan komposisi pati yang terkandung dalam biji durian yaitu 46,2\% pada biji durian. Mikroorganisme yang mengkonsumsi pati akan membentuk pori-pori dalam matrik polismer dan memberikan gugus-gugus yang rentan untuk terdegradasi (Park, 2002).

Tahap terakhir yaitu uji tensile strength. Faktor penting yang mempengaruhi sifat mekanik pada suatu plastik adalah affinitas antara tiap komponen penyusunya (Damayanti, 2003).

Kekuatan suatu bahan dipengaruhi oleh ikatan kimia penyusunnya. Sifat mekanik yang dianalisis meliputi kekuatan tarik dan kemuluran. Serta penilaian modulus young digunakan sebagai acuan untuk menentukan kekuatan mekanik bioplastik sebagai tolak ukur keelastisitasan sebuah plastik. Kekuatan tarik merupakan tegangan maksimum yang dibutuhkan oleh spesimen untuk menahan gaya yang diberikan.

Pengujian kekuatan tarik dari campuran rumput laut, penambahan pati biji durian dan pati singkong merupakan faktor yang penting untuk menentukan kondisi optimum sifat mekanis bioplastik yang diinginkan.

Data sifat mekanik bioplastik rumput laut, penambahan pati biji durian dan pati singkong yang dihasilkan dapat dilihat pada Tabel 3 berikut.

Tabel 3. Hasil Uji Tensile Strength

\begin{tabular}{llll} 
Komposit Film & $\begin{array}{l}\text { Tensile Strength } \\
(\text { MPA })\end{array}$ & $\begin{array}{l}\text { Besar Perpanjangan } \\
(\%)\end{array}$ & $\begin{array}{l}\text { Pemanjangan ketika break } \\
(\%)\end{array}$ \\
\hline $\begin{array}{l}\text { Rumput laut \& } \\
\text { Pati Singkong \& } \\
\text { Pati Biji Durian }\end{array}$ & 4.69 & 1.92 & 2.02 \\
\hline
\end{tabular}

Dari data tensile strength dapat dilihat bahwa biji durian mempunyai kekuatan pemanjangan (tensile strength) sebesar $4.69 \mathrm{mPA}$ serta hasil perpanjangan 1,92\% dan perpanjangan putus 2,02\%. Hal ini dipengaruhi oleh besarnya kandungan amilosa dari limbah biji durian. Amilosa adalah polimer rantai lurus D-glukosa yang memainkan peran yang sangat penting dalam pembentukan lembaran film yang kuat. Semakin tinggi kandungan amilosa semakin tidak elastis lembaran film (D. R. Lu, C. M. Xiao, and S. J. Xu, 2009).

\section{KESIMPULAN}

Berdasarkan pada penelitian komposit film dari campuran rumput laut, pati singkong dan polisakarida yang berasal dari biji durian telah dikembangkan. Film bioplastik dari limbah biji durian telah menunjukkan karakteristik yang menjanjikan untuk aplikasi bioplastik dalam industri pengemasan yang berdasarkan pada karakteristik gugus fungsi, mekanis dan kemampuan terurai. Hal ini ditinjau dari hasil pengujian terhadap komposit film bioplastik pada penambahan pati limbah biji durian, dimana komposit film bioplastik dari pati biji durian mempunyai kemampuan 87,43\% terdegradasi dalam tanah selama 14 hari. Selain itu, film bioplastik biji durian memiliki kekuatan pemanjangan (tensile strength) sebesar $4.69 \mathrm{mPA}$ dan hasil perpanjangan 1,92\% serta perpanjangan putus $2,02 \%$. Kemudian, setelah dilakukannya Uji FTIR diketahui bahwa Spektra IR menunjukkan tidak adanya gugus fungsional baru, dengan kata lain secara kimia tidak terjadi perubahan, sehingga proses pembuatan bioplastik merupakan pencampuran secara fisik. 


\section{REFERENSI}

Ali, M. S. Memon. 2008. Incorporation of Enteromorpha procera Ahlner as nutrition supplement in chick's feed. International Journal Biology and Biotechnology, 211-214.

A. Sofia, A.T. Prasetya, dan E. Kusumastuti. 2017. Komparasi Bioplastik Kulit Labu Kuning Kitosan dengan Plasticizer dari Berbagai Variasi Sumber Gliserol. Indonesian Journal of Chemical Science, 6(2): 110-116.

Afif, M. 2003. Pembuatan Jenang dengan Tepung Biji Durian (durio zibethinus Murr.). Skripsi, Semarang: Universitas Negeri Semarang.

Avella, M., Buarovska, A., Errico, M.E., Gentile, G., Grozdno, A., 2009, Eco-Challenges of Bio-Based Polymer Composites, Materials, 2, 911-925.

Coles R, Dowell DM. dan Kirwan MJ. 2003. Food Packaging Technology. London: Blackwell Publishing, CRC Press.

Djaeni, M. 2010. Kelayakan Biji Durian Sebagai Bahan Pangan Alternatif: Aspek Nutrisi dan tekno Ekonomi. Riptek: 37-45.

D. R. Lu, C. M. Xiao, and S. J. Xu, 2009 . Starch-based completely biodegradable polymer materials. Express Polym. Lett., 3(6): 366-375,.

Dyah, O. Y. Primarini. 2000. Some Enzyme Properties of Raw Starch Digesting Amylases of Sterptomyces sp. Starch: 28-32.

Fahmi, Melta Rani. 2018. Magot Pakan Ikan Protein Tinggi \& Biomesin Pengolah Sampah Organik. Jakarta : Penebar Swadaya.

Gunawan, I., Deswita, Aloma, dan Sudirman. 2007. Modifikasi polyethylene sebagai polimer komposit biodegradable untuk bahan kemasan. Jurnal Sains Materi Indonesia: 37-42.

Martina, M. I. Sufiya Putri. 2016. Analisis Plastik Biodegradable Berbahan Dasar Nasi Aking. Jurnal Ilmu Pendidikan Fisika: 9-12.

Melanie, Cornelia., Rizal Syarief , Hefni Effendi, Budi Nurtama. 2013. Pemanfaatan Pati Biji Durian (Durio zibethinus Murr.) dan Pati Sagu (Metroxylon sp.) Dalam Pembuatan Bioplastik. J. Kimia Kemasan, 35(1): 20-29.

Park, H. 2002. Preparatio and Properties Biodegradable Thermoplasttic Starch/Clay Hybrids. Macromolecular Materials and Engineering: 553-558.

Said, A. 2018. Sintesis Plastik Biodegradable Berbahan Komposit Pati Sagu- Kitosan Sisik Ikan Katamba (Lethrinus lentjam.). Jurnal Inovasi Pendidikan Sains: 23-30.

Satriawan MB, Ilmiating Illing. 2017 .Uji FTIR Bioplastik dari Limbah Ampas Sagu dengan Penambahan Variasi Konsentrasi Gelatin. Jurnal Dinamika, 8(21): 1-13.

Sitomurang, R. 2009. Usaha Pembuatan Keripik Biji Durian Bumbu Balada dengan Tingkat Kepedasan Berbeda. Skripsi. Medan: Universitas Sumatera Utara.

Suryanto, Heru., Nanang Eko Wahyuningtyas, Reza Wanjaya, Poppy Puspitasari, Sukarni. 2016. Struktur dan Kekerasan Bioplastik dari Pati Singkong. Prosiding Seminar Nasional Terapan Teknologi.

Tokiwa, Y., B.P. Calabia, C.U. Ugwu, and S. Aiba. 2009. Biodegradability of Plastics. Int. J. Mol. Sci. 10: $3722-3742$.

Ummah, Natiqoh Al. 2012. Uji ketahanan Biodegradable Plastic Berbasis Tepung Biji Durian Terhadap Air dan Pengukuran Densitasnya. Skripsi. Semarang: Universitas Negeri Semarang. 
Utami, Yuli Darni dan Herti. 2010. Studi Pembuatan Dan Karakteristik Sifat Mekanik Dan Hidrofobilitas Bioplastik Dari Pati Sorgum. Jurnal Rekayasa Kimia Dan Lingkungan, 7(4): 190195.

Verraprinita Arizal, Yuli Darni, Edwin Azwar, Lia Lismeri, Herti Utami. 2017. Aplikasi Rumput Laut Eucheuma Cottonii Pada Sintesis Bioplastik Berbasis Sorgum Dengan Plasticizer Gliserol. Prosiding Seminar Nasional Riset Industri Ke 3 Balai Riset dan Standardisasi Industri.

Wekridhany, A. 2012. Pengaruh Rasio Selulosa/ NaOH pada Tahap Alkalinisasi terhadap Peningkatan Produksi Natrium Karboksimetil selulosa ( Na-CMC) dari Residu Rumput Laut Eucheuma Spinossum. Jurnal Penelitian Jurusan Teknik Kimia.

Y., N. 2010. Karakteristik Permen Jelly Rumput Laut Kappaphycus alvarezzi dengan Penambahan Pati Termodikfikasi Sebagai Bahan Pengisi. Skripsi. IPB.

Yamaguchi, V. E. Rubatzky. 1995. Sayuran Dunia. Bandung: ITB.

Zatnika, A dan Istini, S., 2007. Produksi Rumput laut dan Pemasarannya di Indonesia. Seafarming Workshop : Bandar Lampung. 